\title{
Spawanie stopu magnezu z grupy AM metodą MIG
}

\section{Welding of magnesium alloy from AM group by MIG method}

\section{Streszczenie}

Artykuł dotyczy technologicznych aspektów łączenia stopów magnezu z grupy AM metodą MIG z zastosowaniem materiału dodatkowego $z$ grupy $A Z$. $W$ ramach pracy wykonano złącza doczołowe płaskowników o grubości $3 \mathrm{~mm}$ wykonanych z odlewniczego stopu magnezu AM50 z zastosowaniem drutu elektrodowego o średnicy $1,2 \mathrm{~mm}$ wykonanego ze stopu AZ31. Złącza wykonano przy różnych wartościach natężenia prądu spawania. Jakość złączy oceniano na podstawie badań wizualnych i badań mikroskopowych.

\section{Abstract}

The paper presents results of joining magnesium alloys from AM group by MIG method with the use of filler material from $A Z$ group of magnesium alloys. Welding tests were carried out making butt joints of $3 \mathrm{~mm}$ thick plates of casting alloy AM50 using AZ31 alloy electrode wire of diameter $1.2 \mathrm{~mm}$ and argon as the shielding gas. The quality of obtained joints were assessed on the basis of visual inspection and macrostructure examination. Additionally the SEM measurement of main elements distribution in welds also done.

\section{Wstęp}

Stopy na bazie magnezu, jako najlżejsze metaliczne materiały konstrukcyjne, jeszcze do niedawna miały dość ograniczone zastosowanie w przemyśle samochodowym i lotniczym. Głównie z uwagi na niski moduł sprężystości, ograniczoną wytrzymałość i odporność na pełzanie $w$ podwyższonych temperaturach. Także wysoka aktywność chemiczna i wynikająca z niej niska odporność korozyjna powodowały zmniejszone zainteresowanie konstruktorów tymi materiałami [1]. Niewielkie procentowo dodatki pierwiastków stopowych takich jak $\mathrm{Al}, \mathrm{Cu}, \mathrm{Zn}, \mathrm{Mn}$ i pierwiastki ziem rzadkich znacznie poprawiają zarówno właściwości mechaniczne, jak i chemiczne uzyskanych stopów w porównaniu z czystym magnezem. Brak badań nad technologią produkcji i dalszą obróbką (kształtowaniem detali i technologią łączenia) stopów na bazie magnezu istotnie hamuje przemysłowe zastosowanie nowych stopów o polepszonych właściwościach w przemyśle.

Dr inż. Paweł Kołodziejczak, dr hab. inż. Andrzej Kolasa, prof. PW, mgr inż. Krzysztof Skrzyniecki, dr inż. Paweł Cegielski - Politechnika Warszawska.
Odrębnym zagadnieniem dotyczącym elementów ze stopów magnezu jest ich przetwarzanie, w tym łączenie. W początkowej fazie rozwoju technik łączenia magnezu próbowano wykorzystywać tradycyjne metody spawania, jednakże, ze względu na niezadowalające wyniki jakościowe złączy, zaczęto wdrażać nowoczesne metody, np. spawanie laserowe $[1 \div 3]$. Obecnie prowadzone są badania nad technikami łączenia stopów magnezu, które umożliwią zwiększenie wydajności spawania i zmniejszenie kosztów produkcji, przy zredukowaniu negatywnego wpływu procesu produkcyjnego na środowisko.

Niniejsza praca dotyczy technologicznych aspektów łączenia stopów magnezu z grupy AM metodą MIG.

Pilna potrzeba rozwoju tych badań została uwarunkowana zaostrzeniem wymagań dotyczących ochrony środowiska, takich jak hałas, emisja gazów spalinowych [4], przy jednoczesnym dążeniu do podwyższenia bezpieczeństwa środków transportu, takich jak np. dodatkowe wzmocnienia, rozbudowane strefy zgniotu, układy hamowania itp. [5]. Redukcja masy samochodu o $100 \mathrm{~kg}$ powoduje spadek zużycia paliwa o 5\% [6]. Czynniki te wraz ze wzrostem oczekiwań klientów dotyczących komfortu podróżowania (np. klimatyzacja), przy wykorzystaniu tradycyjnych materiałów 
prowadziłyby do znacznego zwiększenia masy pojazdu, a w konsekwencji wzrostu zużycia paliwa i zanieczyszczenia środowiska. W związku z tym konstruktorzy podjęli próby zastępowania elementów stalowych częściami ze stopów aluminium, a ponieważ efekt był niezadowalający, to obecnie części te wykonywane są ze stopów magnezu.

Badania nad technologią spawania prowadzone są głównie na stopach MgAlZn oraz MgZnCu. Mimo niewielkiego zainteresowania stopami MgAIMn, można przypuszczać, że wysoka odporność na korozję, głównie wywoływaną przez słoną wodę, tej grupy stopów przyczyni się do wzrostu ich zastosowań, w szczególności na blachy karoseryjne [7].

\section{Przygotowanie złączy spawanych}

Do badań wykorzystano stop odlewniczy AM50 z grupy MgAIMn o składzie chemicznym podanym w tablicy I. Jako materiał dodatkowy zastosowano drut o średnicy 1,2 mm wykonany ze stopu AZ31, o składzie chemicznym przedstawionym również w tablicy I.

Tablica I. Skład chemiczny stopów AM50 i AZ31

Table I. Chemical composition of AM50 and AZ31 alloys

\begin{tabular}{|c|c|c|c|}
\hline Oznaczenie stopu & \multicolumn{3}{|c|}{ Dodatki stopowe, \% wag. } \\
\hline- & $\mathrm{Al}$ & $\mathrm{Mn}$ & $\mathrm{Zn}$ \\
\hline AM50 & 5 & 0,3 & $<0,2$ \\
\hline AZ31 & 3 & 0,17 & 1 \\
\hline
\end{tabular}

Złącza wykonywano ręcznie metodą MIG, zmieniając natężenie prądu spawania, jako gaz osłonowy stosowano czysty argon.

Do wykonania złączy spawanych użyto płaskowników ze stopu AM50 o wymiarach 50 × 100 × 3 mm. Materiał wyjściowy miał postać prostopadłościanu wyciętego z odlewu. W celu wyeliminowania wpływu struktury wynikającej z technologii wytwarzania (struktura dendrytyczna - ukierunkowana) wykonano badania metalograficzne na dwóch prostopadłych do siebie powierzchniach, po ich uprzednim wypolerowaniu i wytrawieniu. Obrazy makrostruktur pochodzących z tych powierzchni nie różniły się od siebie, co świadczyło o braku anizotropii struktury $\mathrm{w}$ badanym materiale. Następnie w sposób mechaniczny (przy użyciu piły taśmowej) wycięto płaskowniki o grubości $3 \mathrm{~mm}$, zachowując dokładność $\pm 0,1 \mathrm{~mm}$. Tak przygotowane płaskowniki spawano łukowo metodą MIG wzdłuż krawędzi o długości $100 \mathrm{~mm}$. Powierzchnie styku łączonych próbek przed zamontowaniem w uchwycie ustalająco-mocującym czyszczono z warstwy trudnotopliwych tlenków. Przygotowanie tych powierzchni prowadzono w dwóch etapach: przez mechaniczne usunięcie warstwy tlenków (przeszlifowanie papierem ściernym) i następnie umycie acetonem tych powierzchni. Ze względu na wysoką aktywność chemiczną stopów magnezu operacje te wykonywano bezpośrednio przed spawaniem.

W pierwszym etapie wykonano spoiny sczepne, zachowując odstęp $2 \mathrm{~mm}$ między łączonymi płaskownikami, następnie tak przygotowane próbki montowano na specjalnie wykonanej podkładce w celu prawidłowego uformowania grani.

\section{Badania wizualne}

Pierwszym etapem badań otrzymanych złączy były badania wizualne polegające na obserwacji otrzymanych złączy okiem nieuzbrojonym od strony lica i strony grani (tabl. II). Podczas tych badań starano się ocenić prawidłowość uzyskania przetopu i poprawność geometryczną spoin.

Spoina wykonana przy natężeniu prądu 66 A charakteryzuje się regularnym kształtem, przy nieznacznie zróżnicowanej szerokości, co było spowodowane zmienną prędkością ręcznego prowadzenia uchwytu elektrodowego. Lico jest nadmiernie wypukłe, z widoczną łuską charakterystyczną dla spawania metali lekkich. Powierzchnia blachy na granicy wtopienia jest odbarwiona na skutek działania ciepła łuku, strefa ta jest wąska. Obserwacje złącza od strony grani nie wykazały znaczących nieprawidłowości w jego kształcie, jest ono regularne bez widocznych porowatości. Natomiast dla spoiny wykonanej przy natężeniu 73 A można zauważyć znaczącą nieregularność lica spoiny, jak również powiększanie się jego szerokości na długości złącza. Obserwacja od strony grani potwierdza fakt, że złącze to było wykonane $z$ większą energią liniową niż złącze wykonane przy prądzie $66 \mathrm{~A}$. Zwiększenie energii liniowej wynikało bezpośrednio ze zwiększenia natężenia prądu spawania, ale także mogło być spowodowane zmianą prędkości spawania. Zwiększenie natężenia prądu o 3 A praktycznie nie wpłynęło na kształt spoiny, zaś widoczna zmiana szerokości spoiny wynika bezpośrednio ze zmiany prędkości spawania, a tym samym energii liniowej. W przypadku spoiny wykonanej przy natężeniu 82 A zaobserwowano znacznie większą szerokość spoiny wynikającą z większej energii liniowej spowodowanej wzrostem natężenia prądu. Jednakowa szerokość spoiny na jej całej długości świadczy o stabilnym prowadzeniu palnika podczas spawania. Na podstawie braku charakterystycznej łuski można stwierdzić, że otrzymane jeziorko podczas spawania miało duże rozmiary i pozostawało ciekłe znacznie dłużej niż dla próbek wykonanych przy niższej energii liniowej. Na podstawie złącza wykonanego przy natężeniu 94 A zaobserwowano, że było wykonane przy zbyt dużej energii liniowej, o czym świadczy szerokość lica i obniżenie powierzchni łączonych płaskowników będącej w obszarze spoiny. Mimo korygowania tej energii przez zwiększenie prędkości spawania przez operatora, było to 
Tablica II. Spoiny wykonane przy różnym natężeniu prądu spawania

Table II. Welds made with different welding current

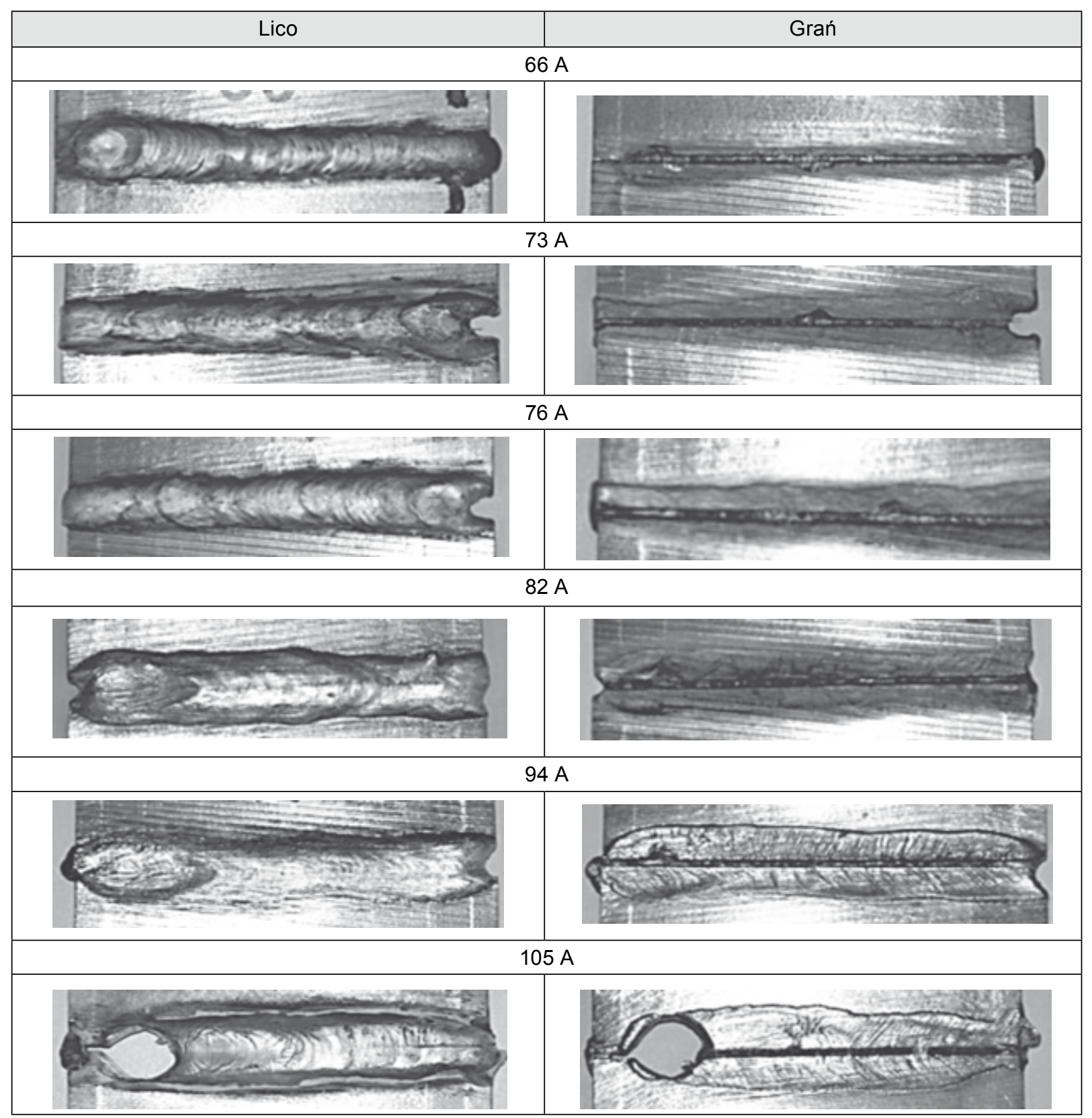

niemożliwe do precyzyjnego kontrolowania. Złącze wykonane przy prądzie 105 A jest wykonane nieprawidłowo ze względu na przepalenie materiału w ostatniej fazie spawania i wystąpienie pęknięcia wzdłuż osi spoiny (pęknięcie gorące), co w bezpośredni sposób świadczy o nadmiernej ilości energii wprowadzonej do materiału w czasie procesu spawania.

\section{Badania metalograficzne}

W celu przygotowania próbek do badań makroskopowych otrzymane złącza przecięto mechanicznie prostopadle do osi spoiny, wyszlifowano i wypolerowano.
Tak wykonane powierzchnie trawiono nitalem przez ok. $30 \mathrm{~s}$. Uzyskane zgłady metalograficzne poddano obserwacjom na mikroskopie świetlnym Olympus XI70 z cyfrową rejestracją obrazu.

$\mathrm{Na}$ podstawie badań wizualnych do dalszej analizy metalograficznej wybrano spoiny wykonane przy natężeniu prądu od $66 \mathrm{~A}$ do $94 \mathrm{~A}$, eliminując złącze wykonane przy natężeniu 105 A ze względu na ubytek materiału w końcowej strefie złącza i wystąpienie pęknięcia wzdłuż osi spoiny.

Spoina przedstawiona na rysunku 1, wykonana przy natężeniu prądu $66 \mathrm{~A}$, charakteryzuję się pełnym przetopem, pełną symetrią, brak jest widocznych porowatości, pęknięć i przyklejeń. Jedyna niezgodność, jaką można zaobserwować, to nadmierna wypukłość lica, będąca skutkiem zbyt małej energii liniowej spawania. 
Zwiększając natężenie prądu do $73 \mathrm{~A}$, otrzymano złącze o znacznie mniejszej wypukłości lica, kosztem powiększenia szerokości spoiny (rys. 2). Zmniejszył się także kąt między liniami wtopienia, przy jednoczesnym

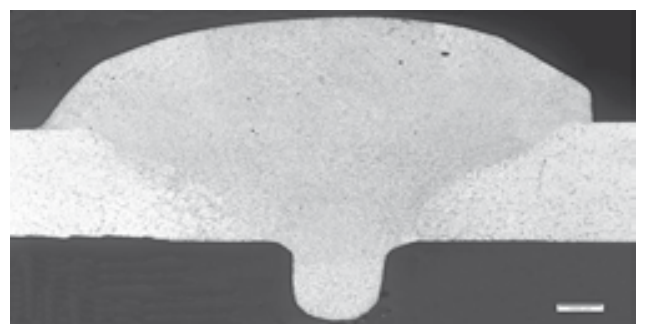

Rys. 1. Makrostruktura spoiny wykonanej przy natężeniu prądu $66 \mathrm{~A}$ Fig. 1. Macrostructure of the weld made with current $66 \mathrm{~A}$

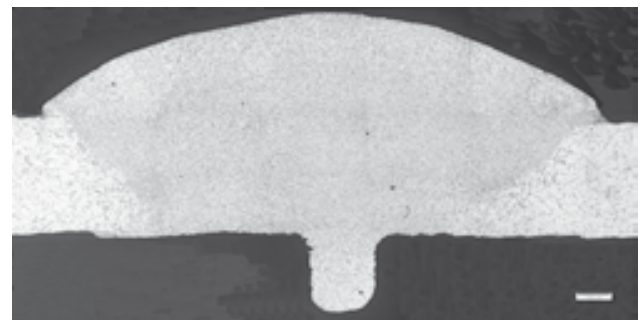

Rys. 2. Makrostruktura spoiny wykonanej przy natężeniu prądu $73 \mathrm{~A}$ Fig. 2. Macrostructure of the weld made with current $73 \mathrm{~A}$

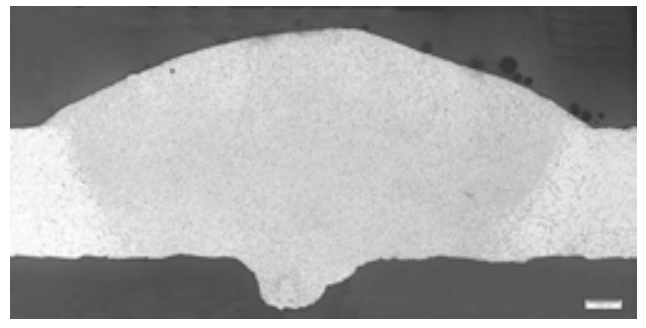

Rys. 3. Makrostruktura spoiny wykonanej przy natężeniu prądu $76 \mathrm{~A}$ Fig. 3. Macrostructure of the weld made with current $76 \mathrm{~A}$

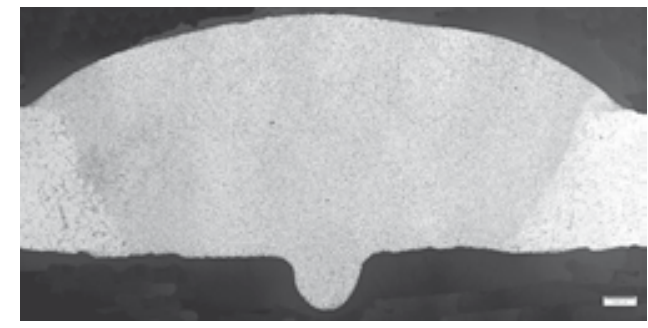

Rys. 4. Makrostruktura spoiny wykonanej przy natężeniu prądu $82 \mathrm{~A}$ Fig. 4. Macrostructure of the weld made current $82 \mathrm{~A}$

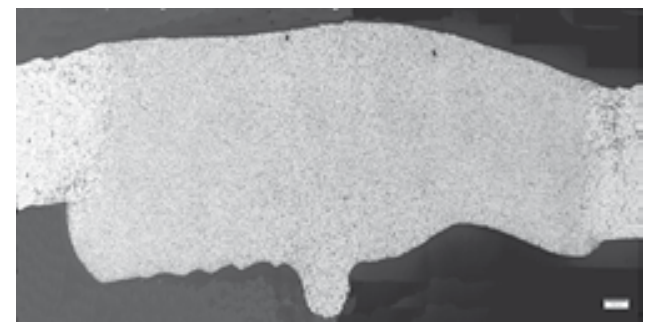

Rys. 5. Makrostruktura spoiny wykonanej przy natężeniu prądu $94 \mathrm{~A}$ Fig. 5. Macrostructure of the weld made current $94 \mathrm{~A}$ zachowaniu ich symetryczności. Fakt ten w bezpośredni sposób wpływa na zmniejszenie deformacji podczas procesu spawania i polepszenie właściwości wytrzymałościowych złącza.

Spoina wykonana przy natężeniu 76 A (rys. 3) charakteryzuje się podobnym kształtem jak spoina przedstawiona na rysunku 2 . Niewielkie różnice $w$ geometrii wynikają z ręcznego prowadzenia uchwytu elektrodowego i tym samym braku powtarzalności w głównej mierze prędkości spawania.

Spoina przedstawiona na rysunku 4 charakteryzuje się prawidłową geometrią, jednak w zestawieniu z poprzednimi spoinami (wykonanymi przy niższym natężeniu prądu) jej szerokość jest znacznie większa.

Zwiększenie natężenia prądu do 94 A spowodowało nadmierny wzrost ilości ciepła wprowadzanego do złącza i tym samym nadmierną dynamikę procesu niemożliwą do opanowania przez spawacza (rys. 5). Otrzymana spoina charakteryzuje się nieregularnym kształtem, bez jakiejkolwiek symetrii. Nastąpił nadmierny wyciek materiału od strony lica, który w przypadku niestosowania podkładki ceramicznej skutkowałby przepaleniem materiałów spawanych.

Przeprowadzona analiza makrostruktury otrzymanych połączeń pozwala stwierdzić, że otrzymane złącza są wolne od porowatości i pęknięć, a strefa wpływu ciepła ma podobną wielkość dla wszystkich parametrów spawania (wynosi ok. $2 \mathrm{~mm}$ ), co wynika z wysokiego współczynnika przewodzenia ciepła magnezu.

\section{Badania SEM}

$\mathrm{Na}$ podstawie wcześniejszych badań do analizy SEM wytypowano złącze wykonane przy natężeniu $82 \mathrm{~A}$. Dla tej próbki wykonano analizę składu chemicznego w charakterystycznych obszarach (SWC, linia wtopienia), wykorzystując elektronową mikroskopię skaningową - mikroskop Philips XL-30 LaB6 wyposażony w mikroanalizator rentgenowski DX4i/EDAX.Z dokonano analizy rozkładu pierwiastków. Do badań przygotowano nietrawione zgłady metalograficzne (rys. 6).

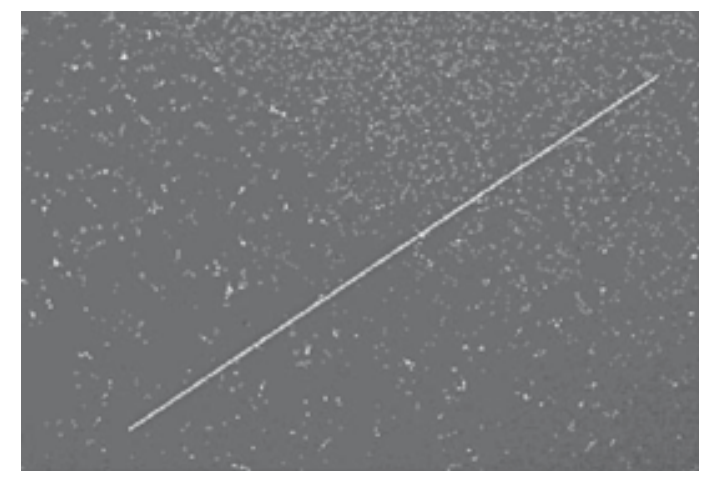

Rys. 6. Obraz SEM z naniesioną linią pomiaru składu chemicznego Fig. 6. SEM image with the line of chemical composition measurement 
Analiza jakościowa składu chemicznego wykazała, że w strefie spoiny nastąpiło znaczne ujednorodnienie struktury, a tym samym ujednorodnienie składu, potwierdzone mniejszymi pikami od głównych pierwiastków stopowych (rys. 7).

$\mathrm{Na}$ podstawie ilościowej analizy powierzchniowej z obszaru linii wtopienia można zauważyć, że rozkład magnezu i aluminium jest bezpośrednio związany ze strukturą i w miejscach, gdzie pojawia się większa zawartość aluminium, spada zawartość magnezu (rys. 8). Natomiast cynk jest rozłożony równomiernie niezależnie od tego, czy jest to materiał rodzimy, czy strefa przetopiona, mangan zaś jest rozlokowany w sposób przypadkowy w pojedynczych punktach.

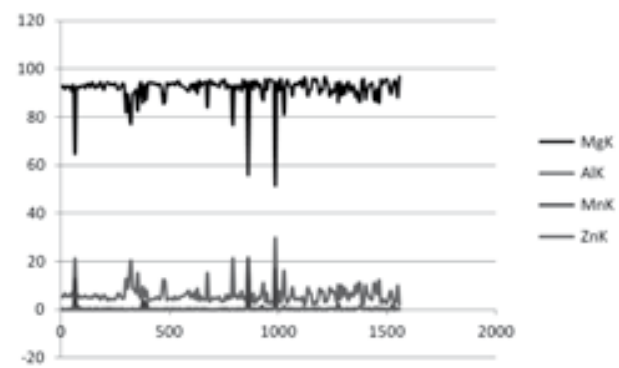

Rys. 7. Rozkład liniowy pierwiastków wzdłuż linii pokazanej na rys. 6 Fig. 7. The line distribution of main elements along the line shown in fig. 6
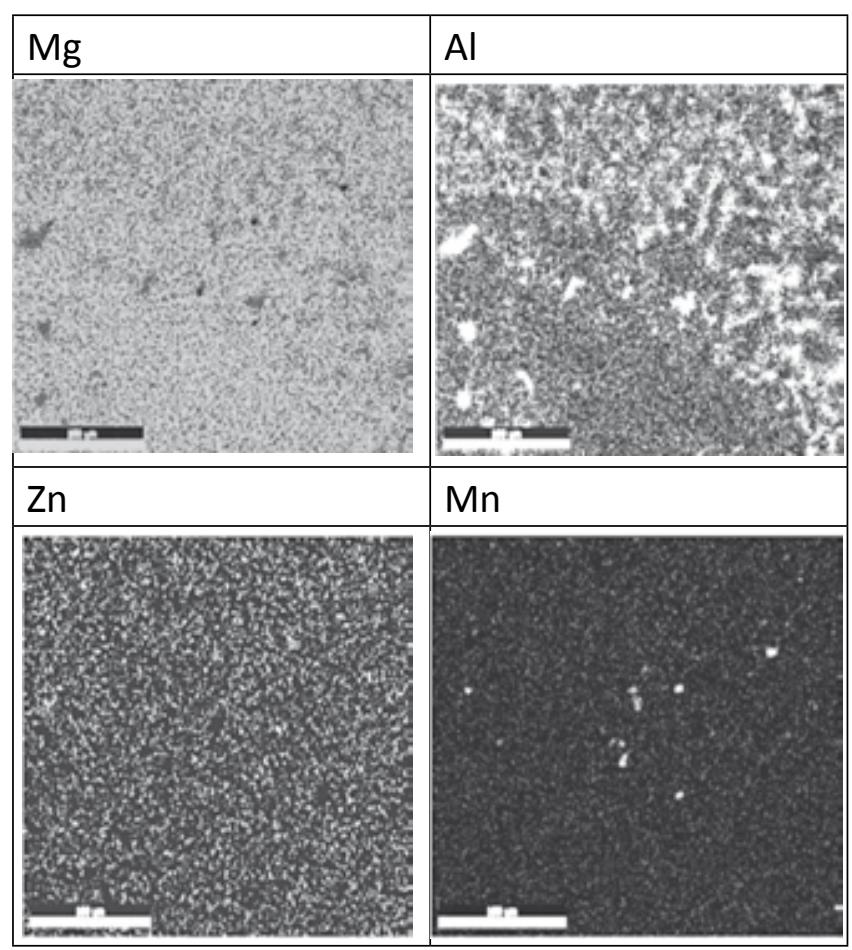

Rys. 8. Rozkład głównych pierwiastów stopowych w obszarze linii wtopienia

Fig. 8. Distribution of main alloing elements in the fusion line zone

\section{Podsumowanie}

$\mathrm{Na}$ podstawie przeprowadzonych badań można stwierdzić, że wraz ze wzrostem natężenia prądu spawania stopu magnezu AM50 metodą MIG wzrasta szerokość spoiny aż do pojawienia się deformacji od strony grani. Przy niskim natężeniu prądu zauważalna jest charakterystyczna dla spawania stopów lekkich łuska, jak również nadmierny nadlew lica spoiny. Przy maksymalnym natężeniu prądu zastosowanym w pracy (105 A) pojawiło się gorące pęknięcie w osi próbki. Wykonane badania dowiodły, że stosując odpowiednie natężenie prądu spawania (z przedziału $73 \div 82 \mathrm{~A}$ ), można wykonać prawidłowe złącza spawane metodą MIG płaskowników o grubości $3 \mathrm{~mm}$. Proces spawania przebiega w sposób stabilny, możliwy do kontrolowania przez spawacza.

Badania SEM nie wykazały zmian udziału poszczególnych pierwiastków na skutek spawania łukowego, co może świadczyć o dobrej osłonie jeziorka spawalniczego. Wykonane rozkłady pierwiastków pozwoliły określić obszary lokalizacji poszczególnych pierwiastków stopowych.

\section{Literatura}

[1] Kołodziejczak P., Kalita W.: Properties of $\mathrm{CO}^{2}$ laser-welded butt joints of dissimilar magnesium alloys, Jurnal of Materials Pocessing Technology, 01/ 2009, 1122-1128.

[2] Kołodziejczak P., Kalita W, Kwiatkowski L., Grobelny M., Hoffman J., Quality Assessment of $\mathrm{CO}^{2}$ Laser-Welded Joints of Magnesium Alloys, CO-MAT-TECH 2005, pp. 563-571, Trnava 2005.

[3] Kołodziejczak P., Kolasa A., Kalita W, Properties of laser welded joints of magnesium alloys, International Doctoral Seminar, Smolenice 2006.

[4] Mordike B.L., Ebert T.: Magnesium. Properties - applications - potential. Material Science and Engineering, A302, 2001, pp.37-45.
[5] Aghion E., Bronfin B., Eliezer D.: The role of the magnesium industry in protecting the environment. Journal of Materials Processing Technology, vol. 117, 2001, s. 381-385.

[6] Esperza J. A., Davis W. C., Trillo E. A., Murr L. E.: Frictionstir welding of magnesium alloy AZ31B. Journal of Materials Science no. 21, 2002, s. 917-920.

[7] Longworth S.J.P.: The Bolting of Magnesium Components in Car Engines. Dissertation for the degree of Master of Philosophy to the Univ. of Cambridge, August 2001.

[8] Welding Handbook, vol. 3, part 1, chapter 2: Magnesium and magnesium alloys. VIII ed., Ed.: W.R. Oates, American WeIding Society. 